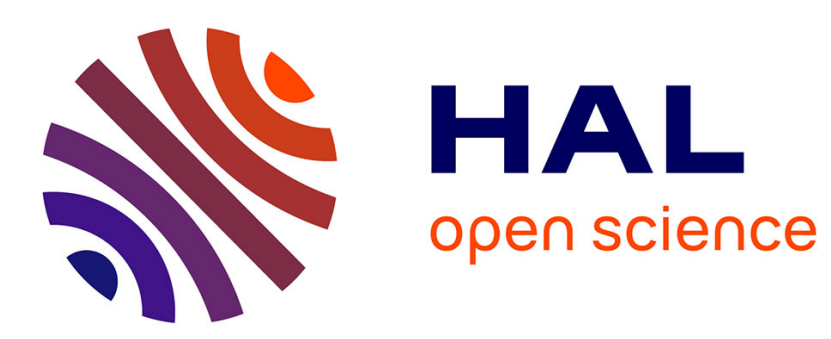

\title{
The Influence of Digital Convergence/Divergence on Digital Media Business Models
}

\author{
Zvezdan Vukanovic
}

\section{To cite this version:}

Zvezdan Vukanovic. The Influence of Digital Convergence/Divergence on Digital Media Business Models. 17th International Conference on Entertainment Computing (ICEC), Sep 2018, Poznan, Poland. pp.152-163, 10.1007/978-3-319-99426-0_13 . hal-02128611

\section{HAL Id: hal-02128611 \\ https://hal.inria.fr/hal-02128611}

Submitted on 14 May 2019

HAL is a multi-disciplinary open access archive for the deposit and dissemination of scientific research documents, whether they are published or not. The documents may come from teaching and research institutions in France or abroad, or from public or private research centers.
L'archive ouverte pluridisciplinaire HAL, est destinée au dépôt et à la diffusion de documents scientifiques de niveau recherche, publiés ou non, émanant des établissements d'enseignement et de recherche français ou étrangers, des laboratoires publics ou privés. 


\title{
The influence of digital convergence/divergence on digital media business models
}

\author{
Zvezdan Vukanovic ${ }^{1[0000-0003-2091-0928]}$ \\ ${ }^{1}$ Abu Dhabi University, Abu Dhabi, UAE \\ zvezdan. vukanovicaadu.ac.ae
}

\begin{abstract}
The key objectives of this article is to analyze and discuss the influence of digital convergence/divergence on digital media business models. The identification of sustainable and hyper-competitive digital media business models is an urgent priority as continuing decline in audiences, collapse of traditional/old media organizations and the decrease of the economic and social influence of traditional media pose a major threat to media, democracy, ICT and telecommunications industry, with scholars agreeing that further erosion of media industry also have major implications for the advertising industry and a wide range of content producers. The successful digital media and ICT corporations will have to act more as corporate planners, as well as 'cloud', 'on-demand' and 'ubiquitous' content and distributor disaggregators, than traditional content and advertising providers.

In summary, the second decade of the 21 st century digital media is apparently becoming increasingly interactive, mobile, immersive, and ubiquitous. Furthermore, the future of the media appears to be specifically oriented towards the establishment of, networked, 3D, on-demand, broadband and unicast as well as multimedia and hypermedia models of distribution, communication and content creation. Therefore, it is crucial that profitable digital media companies realize that media divergence can successfully perform as vendor lock-in a top-down corporate process and a bottom-up consumer-driven process. The digital business models influenced by digital convergence/divergence will focus on aggregate multi-platform distribution, complementarities, vendor lock-in, interoperable and networked media and ICT ecosystem, massive personalization/customization, user interface.
\end{abstract}

Keywords: digital convergence digital media business models, media market competition.

\section{Introduction - Contextual Background: The need for the application of digital media business models}

One of the challenges of studying digital media business models in the age of media convergence is that the concept is so multifaceted and broad that it has multiple meanings. As a result, the academic and scholarly literature in this area is diverse and remains under-researched, under-explored and under-developed from both a theoretic and an empirical perspective. This article reviews scholarly studies that identify the range of strategic options available for sustainable business models in digital media industry. 
Identification of sustainable and hyper-competitive digital media business models is an urgent priority as continuing decline in audiences and collapse of traditional/old media organizations pose a major threat to media, democracy, ICT and telecommunications industry, with scholars agreeing that further erosion of media industry also have major implications for the advertising industry and a wide range of content producers.

Referred to in the industry as 'audience fragmentation' or 'disaggregation', this breakdown of large mass audiences of mass media is resulting in both advertising volume and rates falling within the dominant commercial media business model [1]. As Henry Jenkins warns, 'monolithic blocks of eyeballs are gone' [2]. Notwithstanding, few media organizations have settled on a viable long-term strategy for making money in a sustainable fashion' [3]. As a result of this lack of foresight, media organizations - particularly news companies and departments - have not invested sufficiently in research and development to expand or update their product line over recent decades [3]. Importantly, many news media have invested less than 1 per cent of their operating budgets in R\&D to develop new products and new business models. The cost of failing to recognize the potential and public demand for new forms of content and distribution methods has been that media organizations have not developed new products tailored to the Web 2.0 and Web 3.0 environment of social media and social networks or the changing media and ICT economy [4] .

\section{The decrease of the economic and social influence of traditional media}

The lack of efficient development of new business models caused the decrease of the economic and social influence of traditional media (print, radio, TV, and printed books). Accordingly, eBooks (excluding educational publications) reached $\$ 8.2$ billion in sales by 2017 and surpassed printed book sales, whose sales fall from $\$ 11.9$ billion in 2012 to $\$ 7.9$ billion in 2017 . In addition, the number of e-books sold in the United States increased from 69 million in 2010 to 221 million in 2016. By contrast, the total weekday circulation of U.S. newspapers decreased during the last two decades for almost $50 \%$ (i.e. from 60 to 30 million).

\section{Literature review and Discussion on Recent Models of Convergence in Media Research}

The concept of convergence is frequently used both in the academic field and within the media industry to denote the ongoing restructuring of media companies as well as to describe the latest developments in media forms, distribution, and consumption [5]. However, there is currently no generally accepted definition of the concept. Depending on the context, the meaning and connotations vary. It is generally accepted among media business scholars that convergence denotes the actual process toward a more efficient management of the media value chain. The use of the concept has therefore developed from being mainly connected with digitalization in media technology to also include elements of integration, combination, competition and divergence. 
The digital media convergence is an ongoing and continuous process of media industry development based contrasted and complemented with the process of digital media divergence [5]. In the table 1, the author provides the conceptual and applicative definitions of digital media convergence model.

Table 1. The conceptual and applicative definitions of digital media convergence model

\begin{tabular}{|c|c|}
\hline Authors & $\begin{array}{c}\text { Main Digital Media Convergence } \\
\text { Model }\end{array}$ \\
\hline $\begin{array}{l}\text { Greenstein and Khanna (1997, pp. 203- } \\
\text { 204) [6] }\end{array}$ & substitutes and complements \\
\hline Jenkins (2001) [7] & $\begin{array}{l}\text { technological, economic, social or or- } \\
\text { ganic, cultural and global convergence }\end{array}$ \\
\hline Lawson-Borders (2003) [8] & $\begin{array}{l}7 \text { c: Communication, commitment, } \\
\text { cooperation, compensation, culture, } \\
\text { competition, and customer }\end{array}$ \\
\hline Lee (2003) [9] & $\begin{array}{l}\text { Data convergence } \\
\text { Structural convergence } \\
\text { Application convergence } \\
\text { Industrial convergence } \\
\end{array}$ \\
\hline Dennis (2003) [10] & $\begin{array}{l}\text { "incremental awakening"- the 1980s, } \\
\text { "early adoption"- early to mid-1990s, } \\
\text { "uncritical acceptance"-late 1990s, } \\
\text { and "presumptions of failure"-early } \\
2000 \mathrm{~s}\end{array}$ \\
\hline Huang, et al (2006) [11] & $\begin{array}{ll}\text { - } & \text { content convergence, } \\
\text { - } & \text { form convergence (or techno- } \\
& \text { logical convergence) } \\
\text { - } & \text { corporate convergence } \\
\text { - } \quad \text { role (of producers and con- } & \text { sumers) convergence }\end{array}$ \\
\hline Meikle and Young (2011) [12] & $\begin{array}{l}\text { Technological convergence } \\
\text { Industrial convergence } \\
\text { Social convergence } \\
\text { Textual convergence }\end{array}$ \\
\hline
\end{tabular}

Jenkins (2001) [7] divides convergence into five areas, technological, economic, social or organic, cultural and global convergence. Technological convergence is the digitalization of all media content, economic convergence deals with the integration of the entertainment industry and the social or organic version of the process handles the consumers. According to Jenkins, cultural convergence is the explosion of new forms of creativity at the intersections of various media technologies, industries and consumers. Finally, global convergence is the cultural hybridity that results from the international circulation of media content. This definition is in line with the notion that convergence is an ongoing process, occurring at various intersections between 
media technologies, industries, content and audiences; it is not an end state [7]. The effects of the process of convergence are visible, measurable and possible to detect, while the actual process might not be [5].

Lawson-Borders (2003) suggests another model of convergence, where the starting point is that convergence is a concept as well as a process. Lawson-Borders has identified seven observations. of convergence all beginning with the letter c: Communication, commitment, cooperation, compensation, culture, competition, and customer. These seven areas are partly overlapping and can serve as a guideline for best practices to expound on convergence both as a concept and a process Lawson-Borders, 2003).

In addition, Lawson-Borders (2003) believes that for convergence to succeed, media firms must:

(a) engage in high quality communication about what the organization is trying to accomplish;

(b) be committed to incorporating convergence into their organizational mission and philosophy;

(c) promote cooperation among everyone involved in the journalistic process "to share stories and ideas;"

(d) revise compensation plans to fairly compensate multimedia journalists for taking on the new roles and responsibilities required by convergence;

(e) facilitate the blending of different cultures in the newsroom (i.e., print, radio, television, and online) [13];

(f) develop strategies and alliances capable of allowing media firms to successfully compete in local markets and globally; and

(g) develop convergence strategies capable of serving evolving consumer needs in a dynamic and increasingly competitive/challenging marketplace (pp. 94-96).

Furthermore, Lee (2003) describes four categories and eight levels of digital convergence:

1. Data convergence (Media convergence and Domain convergence)

2. Structural convergence (Architecture convergence and Infrastructure convergence)

3. Application convergence (Platform convergence and Device convergence)

4. Industrial convergence (Intra-industry convergence and Inter-industry convergence) [9]

Dennis (2003, p. 7) identified four stages of communication industry convergence: "incremental awakening"- the 1980s, "early adoption"- early to mid-1990s, "uncritical acceptance"-late 1990s, and "presumptions of failure"- early 2000s.

Pavlik and McIntosh (2004) state that there are four areas of implications due to convergence:

1. the content of communication,

2. the relationships between media organizations and their publics,

3. the structure of communication organizations and

4. how communication professionals do their work [14] .

Greenstein and Khanna (1997, pp. 203-204) define convergence in terms of substitutes and complements: "Two products converge in substitutes when users consider either product interchangeable with the other. . . . Two products converge in complements when the products work better together than separately or when they work 
better together now than they worked together formerly." Allison, DeSonne, Rutenbeck, and Yadon (2002, p. 61) consider convergence as a "business trend where previously separate industries ... are converging through megamergers, buyouts, partnerships and strategic alliances . [15] Allison, DeSonne, Rutenbeck, and Yadon, 2002 " Huang, et al (2006) identify four categories of media convergence: content convergence, form convergence (or technological convergence), corporate convergence, and role (of producers and consumers) convergence.

Meikle and Young (2011) observe that convergence can be understood in four dimensions:

- technological - the combination of computing, communications and content around networked digital media platforms;

- industrial - the engagement of established media institutions in the digital media space, and the rise of digitally-based companies such as Google, Apple, Microsoft and others as significant media content providers;

- social- the rise of social network media such as Facebook, Twitter and YouTube, and the growth of user-created content; and

- textual - the re-use and remixing of media into what has been termed a 'transmedia' model, where stories and media content (for example, sounds, images, written text) are dispersed across multiple media platforms.

Importanlty, media convergence refers to an evolutionary process, not an endpoint. It is not simply a technological shift, but it alters relationship between existing technologies, industries, markets, genres, and audiences [2]. Furthermore, convergence alters the business operation of the digital media industry.

\section{Driving forces of media convergence}

As the concept of media convergence appears to be multifaceted process there are apparently many driving forces behind convergence and the increased interest in the concept [16] . Most dominant driving forces include, but are not limited to:

(a) technological innovation, including the rise of the Internet and the digital revolution;

(b) the exponential growth of internet data, the computational power and the transfer of internet data

(c) deregulation/liberalization and globalization, including passage of the Telecommunications Act of 1996, formation of the European Union and the privatization of telecommunications and media around the world;

(d) changing consumer tastes and increased consumer affluence;

(e) technological standardization;

(f) the search for synergy (i.e., $1+1=3$ );

(g) increasing global competition (which has resulted in high levels of merger and acquisition activity among media and telecommunication companies around the world); and

(h) repurposing of old media content for distribution via various forms of digital media [17] . 


\section{Discussion: The business and technological impact of media con- vergence/divergence}

In order to become flexible, adaptive, immediate and accessible digital media have to develop personalized, immersive, customized, innovative, engaging and userfriendly applications and, services that can be easily accessed as well as shared. Strategic shift of media business moves toward Internet of Smart Things, Web 3.0 and Web 4.0, cloud media, personalized, ubiquitous, software based, on-demand, wearable and database generated media and distributor of aggregated content (widgetization of media), flattening of distribution chain, content aggregators and multiplatform distribution. Content and multiplatform distribution aggregators are the winners in the digital future as the availability and the internet speed significantly reduces cost of media content as well as distribution.

Moreover, in the near future, contextual and behavioral micro targeting in advertising will be more prevalently supported by geospatial tagging, location-based marketing in which social interaction becomes a value. Digital media has to offer at the same time personal and, intimate as well as multifocalized experience firstly attempting to build a community, than a marketplace.

Accordingly, media consumption is not becoming exclusively about demand, but it is also becoming about choice that represents a prospective lock in and barrier entry into a digital media ecosystem. Miniaturization in media production and ubiquitous access will inherently favor usage of social media via mobile phones.

As a result of the digital media audience being more divergent due to the increase of media production and its content, the media market is increasingly fragmented and users' taste is more versatile than ever. Different services and applications on the social networks create their own terminal and multiplatform ecosystem that is becoming increasingly unreachable to consumers unless they pay for premium services/applications. What we are now seeing is the distribution platforms converging while the content diverges.

However, a positive side of digital convergence is that it leads to a democratization of content because of the development of web 2.0; where users generate and upload content for a public access [18]. On the other hand, media convergence represents a risk for content producers and distribution operators since most of digital media companies fear a fragmentation or erosion of their markets. Valerie Feldman in her monographic publication 'Leveraging Mobile Media: Cross Media Strategy and Innovation Policy for Mobile Media Communication' further substantiate the competitive and technological advantage of media divergence over media convergence by stating that:

"Multiple utilization of content in the divergent media is one possible leverage for media companies to raise revenue potentials from existing media content and establish multiple revenue streams. The precondition is the production of platform - neutral content that enables repurposing of content according to the syntax specifications of different distribution platforms. The profitability in the media divergent production and distribution is achieved as the content becomes disaggregated and re-bundled according to the characteristics of the medium." [19]. 
Thus, the development of multiple utilization of content decreases the technological and economic importance of media convergence. The proliferation of channels and the increasingly ubiquitous nature of computing and communications rather contributes to media divergence. Even on the device level, the plethora of specific devices does not suggest convergence, either, albeit digitization enforces technological convergence to some extent [20]. Yet, consumers' demand for context specificity as well as parallel media usage at the intersection of various media access modes, devices and contents rather suggest increase in media divergence [21].

Neverthless, Enlund and Lindskog (2000) describe how the range of information from a consumer perspective has widened, as content now is available in many more media channels than before [22]. In this manner, interactivity and online media encourage divergence, but at the same time the technology behind the service and the production work flow, prior to distributing and broadcasting in the different channels, are converging [5] .

Another important characteristic that further favourizes the media divergence over media convergence is the fact that in the digital media distribution channels and platforms the importance of intermediaries is largely minimized. However, one of the few media industry sectors that need media convergence in order to distribute efficiently its media content is IPTV. The reason for increasing interest in media convergence from IPTV industry viewpoint consists in the fact that IPTV channels are dominantly distributed to prospective subscribers via telecom multiplatforms. Despite its reliance on media convergence the industrial sector of IPTV has achieved limited commercial success as presently only $6 \%$ of the global TV viewers are pay IPTV subscribers. Moreover, the global future of IPTV market appears to be relatively uncertain as major international consulting and telecom agencies project that until 2018 the number of pay IPTV subscribers will increase approximately just 19 million per year. Moreover, with network providers pushing towards new digital payment models, and the idea of prioritizing consumer traffic related to online paying services, network neutrality seems to be an issue of the past, while the time of managed internet services has come [23]. This revenue business model trend will further diverge the audience market.

It is advisable to point out that media divergence is particularly profitable if the media company decides to use the 'cloud' vendor lock-in. The main competitive advantage of 'cloud' vendor lock-in is that it makes a customer dependent on a content producer/service/application or distribution channel/platform. This is explained that typical customers are unable to use another vendor without substantial switching costs or inconvenience. This is predominantly a case when there is a lack of compatibility or, interoperability between content producer/service/application and distribution channel/platform.

Although, both the old/traditional and digital media can reach small or large audiences, there are many fundamental differences in terms of the competitive advantage in distribution, production, technology, market targeting that favor digital media over old/traditional media. In the tables 2 and 3 these marking differences are exposed in order to more effectively outline the major conceptual differences between digital and old media. 
Table 2. The common denominators of major paradigmatic shifts in media business models before and after the digital convergence-divergence

\begin{tabular}{|c|c|}
\hline $\begin{array}{l}\text { Media business models before the } \\
\text { digital convergence-divergence }\end{array}$ & $\begin{array}{l}\text { Media business models before the } \\
\text { after convergence-divergence }\end{array}$ \\
\hline $\begin{array}{l}\text { Industrial media dominantly pro- } \\
\text { duced by large multinational corpora- } \\
\text { tions }\end{array}$ & $\begin{array}{l}\text { Personal media primarily produced } \\
\text { by internet users }\end{array}$ \\
\hline Top-down content production & Bottom-up content production \\
\hline $\begin{array}{l}\text { Centralized framework for organi- } \\
\text { zation, production, and dissemination } \\
\text { of media } \\
\text { One to many content distribution }\end{array}$ & $\begin{array}{l}\text { Decentralized (network and on- } \\
\text { demand) based media } \\
\text { Many to many content distribution }\end{array}$ \\
\hline $\begin{array}{l}\text { Linear, One-way media communi- } \\
\text { cation }\end{array}$ & $\begin{array}{l}\text { Interactive and immersive media } \\
\text { communication }\end{array}$ \\
\hline Reaching the audience & Connecting the audience \\
\hline Passive users - Users as Recipients & Active users - Users as participants \\
\hline Static media & Mobile media \\
\hline Economies of scale & $\begin{array}{l}\text { Economies of scope (Long tail Eco- } \\
\text { nomics) }\end{array}$ \\
\hline One-sided platform distribution & $\begin{array}{l}\text { More diversified multi-platform (hy- } \\
\text { permedia and multimedia) distribution, } \\
\text { less hierarchical, and distinguished by } \\
\text { multiple points of production and utility }\end{array}$ \\
\hline $\begin{array}{l}\text { Less available and accessible to the } \\
\text { public, distribution costs and viewing } \\
\text { is more expensive }\end{array}$ & $\begin{array}{l}\text { Generally available and accessible to } \\
\text { the public at little or no cost }\end{array}$ \\
\hline $\begin{array}{l}\text { The time lag between communica- } \\
\text { tions produced by industrial media can } \\
\text { be long (days, weeks, or even months) }\end{array}$ & $\begin{array}{l}\text { Capable of virtually instantaneous re- } \\
\text { sponses; only the participants determine } \\
\text { any delay in response }\end{array}$ \\
\hline $\begin{array}{l}\text { Once created content, it cannot be } \\
\text { altered (once a magazine article is } \\
\text { printed and distributed changes cannot } \\
\text { be made to that same article) }\end{array}$ & $\begin{array}{c}\text { Easily altered content by almost in- } \\
\text { stantaneously editing and writing com- } \\
\text { ments }\end{array}$ \\
\hline Less creative content creation & More creative content creation \\
\hline $\begin{array}{l}\text { Storage capacity for media content } \\
\text { is relatively low }\end{array}$ & $\begin{array}{c}\text { Storage capacity for media content is } \\
\text { very high } \\
\text { Acts as an online database }\end{array}$ \\
\hline $\begin{array}{l}\text { Low level of content categorization } \\
\text { and sharing }\end{array}$ & $\begin{array}{l}\text { High level of content categorization, } \\
\text { annotation and sharing: } \\
\text { Widgets, collaborative tagging, social } \\
\text { classification, social indexing, } \\
\text { and social tagging, folksonomy }\end{array}$ \\
\hline $\begin{array}{l}\text { Less peer-to-peer power } \\
\text { Publisher-Centric }\end{array}$ & $\begin{array}{l}\text { More peer-to-peer power } \\
\text { User-Centric Model }\end{array}$ \\
\hline
\end{tabular}




\begin{tabular}{|c|c|}
\hline & UGC - User generated content \\
\hline Analogue & Digital media \\
& Digital convergence \\
& Mobile and wireless media \\
& Ambient media \\
& Augmented media \\
& Widget(ized) media \\
& Tagged media \\
\hline
\end{tabular}

Table 3. The common denominators of major paradigmatic shifts in media business models before and after the digital convergence-divergence

\begin{tabular}{|c|c|}
\hline Two-dimensional media & 3D media \\
\hline $\begin{array}{l}\text { Traditional market targeting } \\
\text { (B2C and B2B marketing) }\end{array}$ & $\begin{array}{l}\text { Better and more efficient market and } \\
\text { consumer marketing (B2C and C2C) } \\
\text { Nicheization } \\
\text { Social network and online communi- } \\
\text { ties }\end{array}$ \\
\hline Web 1.0 and Web 2.0 & $\begin{array}{c}\text { Web } 3.0 \text { (semantic web) and Web } 4.0 \\
\text { (symbiotic web) }\end{array}$ \\
\hline Value chain & Value network \\
\hline collaborative consumption & collaborative creation \\
\hline producer & produser \\
\hline broadcasting & $\begin{array}{l}\text { Narrowcasting, microcasting and } \\
\text { egocasting }\end{array}$ \\
\hline Interactive media & immersive media \\
\hline consumerism & prosumerism \\
\hline top-down organizational structure & bottom up organizational structure \\
\hline $\begin{array}{l}\text { Upstream supply chain (Push mar- } \\
\text { keting, low-cost producers) }\end{array}$ & $\begin{array}{l}\text { downstream supply chain (customi- } \\
\text { zation, targetization, high margins) }\end{array}$ \\
\hline one to many distribution & many to many distribution \\
\hline symmetric information flow & asymmetric information flow \\
\hline $\begin{array}{l}\text { First build a marketplace, than a } \\
\text { community. }\end{array}$ & $\begin{array}{l}\text { First build a community, than a mar- } \\
\text { ketplace. }\end{array}$ \\
\hline Attention span is longer & Attention span is shorter \\
\hline Owning the accessed content & Sharing the accessed content \\
\hline Searching the data & Searching the metadata \\
\hline Hardware based media & Software based (cloud) media \\
\hline Demand is the king & Choice is the king \\
\hline Industrial, Tangible Economy & $\begin{array}{l}\text { Information, network, intangible, ex- } \\
\text { perience economy }\end{array}$ \\
\hline $\begin{array}{l}\text { Connect individual with the infor- } \\
\text { mation/content/product }\end{array}$ & $\begin{array}{l}\text { Share applications and experience } \\
\text { among groups }\end{array}$ \\
\hline Information based service & $\begin{array}{l}\text { Conversation/Communication based } \\
\text { service }\end{array}$ \\
\hline Partial information acc & ormation access \\
\hline
\end{tabular}




\begin{tabular}{|c|c|}
\hline Place bounded media & Space bounded media \\
\hline Individual/one screen media & Multi-screen media \\
\hline Value is contained in transaction & Value is contained in relationship \\
\hline Information based service & Conversation/Communication based \\
& service \\
\hline Usage-based pricing & Access-based pricing \\
\hline
\end{tabular}

\section{The future research perspectives, outlooks and implications}

Importantly, the future applcation of business models in digital and ICT media will be focused on the following technologies: the Industrial Internet of Things - Industry 4.0 with its major five components: 1 . Cyber-Physical Systems, 2. Internet of Things, 3. Smart Factory, 4. Internet of Services, 5. Smart Product, Internet of Services, autonomous vehicles, 3D printing, Smart Cloud, Quantum computing, nanotechnology, Big Data (Analytics), Smart Cloud, 5G, Cloud computing, edge and fog computing, artificial intelligence, collaborative robots (cobots), industrial robots, augmented reality, digital billbord advertising, USSD - Unstructured Supplementary Service Data, Predictive analytics, Quantum algorithm, Cognitive Computing, Quantum Computing, Cloud Computing, Biointerface \& Gestural Interfaces, Quantifying Emotion, Geo targeting, Wearable technologies with biometric sensors, AI Art, Drone Journalism, Li-Fi, holography, smart grid, smart/intelligent city, Microelectromechanical systems (MEMS).

\section{Conclusion}

The successful digital media and ICT corporations will have to act more as corporate planners, as well as 'cloud', 'on-demand' and 'ubiquitous' content and distributor disaggregators, than traditional content and advertising providers. Moreover, with all these changes, media will need to accommodate various consumer lifestyles. In an increasingly global and mobile digital media landscape, it is easier than ever to reach a large audience, but it is harder than ever to effectively connect with it. Therefore, old media traditional preoccupation was to reach the audience, however, in the age of digital media globalization, digital media companies have a twofold task to reach and connect the audience.

In summary, the second decade of the $21^{\text {st }}$ century digital media is apparently becoming increasingly interactive, mobile, immersive, and ubiquitous. Furthermore, the future of the media appears to be specifically oriented towards the establishment of, networked, 3D, on-demand, broadband and unicast as well as multimedia and hypermedia models of distribution, communication and content creation. Therefore, it is crucial that profitable digital media companies realize that media divergence can successfully perform as vendor lock-in a top-down corporate process and a bottom-up consumer-driven process.

The digital business models influenced by digital convergence/divergence will focus on aggregate multi-platform distribution, complementarities, vendor lock-in, 
interoperabile and networked media and ICT ecosystem, massive personalization/customization, user interface.

\section{References}

[1] Macnamara, Jim. Remodelling media: The urgent search for new media business models. Media International Australia, No. 137, 20-35. November 2010.

[2] Jenkins, H. Convergence Culture. Where Old and New Media Collide. Cambridge: MIT Press, (2006).

[3]. Pavlik, J. Media in the Digital Age. Columbia University Press, New York, (2008).

[4] Macnamara, J. The 21st Century Media (R)evolution: Emergent Communication Practices. New York: Peter Lang, (2010).

[5] Appelgren, E., Convergence and divergence in Media: Different Perspectives. 8th ICCC International Conference on Electronic Publishing Brasilia - DF, Brazil, June, Pages 237-248, 2004.

[6] Greenstein, S., \& Khanna, T. What does industry convergence mean? In D. B. Yoffie (Ed.), Competing in the age of digital convergence (pp. 201-226). Boston: Harvard Business School Press, (1997).

[7] Jenkins, H. Convergence? I Diverge. Technology Review. v.104, 5, 93, (2001).

[8] Lawson-Borders, G. Integrating New Media and Old Media: Seven Observations of Convergence as a Strategy for Best Practices in Media Organizations. JMM, The International Journal on Media Management, Vol. 5 . No. II, 2003.

[9] Lee, W. C. L. Clash of the Titans: Impact of Convergence and Divergence on Digital Media. Unpublished doctoral thesis, Massachusetts Institute of Technology, June 2003.

[10] Dennis, E. E. Prospects for a big idea-Is there a future for convergence? International Journal on Media Management, 5, (1) 7-11, (2003).

[11] Huang, E. Davison K, Shreve, S. Davis, T. Bettendorf, E. and Nair, A. Facing the challenges of convergence: Media professionals' concerns of working across media platforms, Convergence 12 (1), 83-98, 2006.

[12] Meikle, G. and Young, S. Media Convergence. Palgrave, 2011.

[13] Killebrew, K. C. Culture, creativity and convergence: Managing journalists in a changing information workplace. International Journal on Media Management, 5, 39-46, (2003).

[14] Pavlik, J. V. and McIntosh, S. Converging Media: An Introduction to Mass Communication, Pearson, 2004.

[15] Allison, A. W. III, DeSonne, M. L., Rutenbeck, J., \& Yadon, R. E. Tech terms (2nd ed.). Washington, DC: National Association of Broadcasters, (2002).

[16] Wirth, M., Issues in Media Convergence. In Handbook of media Management and Economics, Eds., Alan B. Albarran, Sylvia Chan-Olmsted and Michael O. Wirth, LEA Publishing, Mahvah, N.J. pp. 445-462, (2006).

[17] Wirth, M.O. New media strategy: Convergence-based driving forces \& challenges. Paper presented at the annual convention of the Association for Education in Journalism and Mass Communication, Kansas City, KS, (2003, July 31).

[18] Diehl, S. And Karmatin, M. Media and Convergence Management, Berlin: SpringerVerlag, (2013).

[19] Feldmann, V. Leveraging Mobile Media: Cross-Media Strategy and Innovation Policy for Mobile Media Communication. Springer Science \& Business Media, 2006.

[20] Goldhammer, K. On the myth of convergence. In Mobile media. Content and services for wireless communications, edited by J. Groebel, E. M. Noam and V. Feldmann. Mahwah, NJ: Lawrence Erlbaum Associates, (2005). 
[21] Cole, J. Multitasking bei der Internetnutzung. In E-merging media. Kommunikation und Medienwirtschaft der Zukunft, edited by A. Zerdick, A. Picot, K. Schrape, J. C. Burgelman, R. Silverstone, V. Feldmann, D. Heger, K. and C. Wolff. Heidelberg: Springer, 82-83, (2004).

[22] Enlund N., Lindskog T. Nya redaktionella processer vid flerkanalspublicering. På väg mot medievärlden 2020, in Hvitfelt H., Nygren G. (eds.), Sweden: Studentlitteratur, 2000.

[23] Lugmayr, A. and Dal Zotto, C. Media Convergence Handbook - Vol. 1, Springer-Verlag Berlin Heidelberg, 2016. 